\title{
Do I really have to Teach them to Read and Write? Education Equity Mindset and Teaching Literacy across the College Curriculum
}

\author{
Louis S. Nadelson ${ }^{1}$, Amy Baldwin ${ }^{1}$, Amanda Martin ${ }^{1}$, Ron Novy ${ }^{1}$, Keith Pachlhofer ${ }^{1}$, Kevin Powell ${ }^{1}$, Erin Shaw ${ }^{1}$, \\ Amy Thompson ${ }^{1} \&$ Jeff Whittingham ${ }^{1}$ \\ ${ }^{1}$ University of Central Arkansas, 201 Donaghey Ave., Conway, Arkansas 72035, USA \\ Correspondence: Louis S. Nadelson, Leadership Studies, University of Central Arkansas, Conway, AR, USA. \\ E-mail: lnadelson1@uca.edu
}

Received: November 3, 2021

Accepted: December 1, $2021 \quad$ Online Published: December 15, 2021

doi:10.5539/hes.v12n1p26

URL: https://doi.org/10.5539/hes.v12n1p26

\begin{abstract}
Reading and writing are fundamental skills students need to succeed in college, making literacy development an issue of education equity. The literacy skills can be content-specific, indicating faculty members across disciplines need to support student development of appropriate literacy skills. The extent to which faculty members support student literacy development is likely associated with their literacy-focused education equity mindset. The goal of our research was to document the mindset of faculty members across multiple disciplines. We gathered a combination of quantitative and qualitative data from 345 college faculty members using a survey. We found variations in the mindset strength between disciplines by the number of students taught, gender, and age. Overall, the faculty members held a moderate literacy-focused education equity mindset. The findings have implications for student inclusion, retention, and completion.
\end{abstract}

Keywords: education equity, literacy, student development, mindset, college-ready

\section{Introduction}

Broadening participation in postsecondary education is essential to expanding the opportunity for more people to experience the benefits of a college education. A citizen in the United States without a college education makes on average $62 \%$ of the wage that a citizen with a bachelor's degree earns (Stobierski, 2020). In addition, a college education can significantly influence an individual's quality of life (Trostel, 2015). We argue that the life-long impact of college success increases the need to assure students have the support necessary to achieve a degree.

Support for literacy skill development is critical for students' college success (Armstrong et al., 2015; Cox et al., 2003). Yet, many postsecondary faculty members perceive students need to come to college with well-developed literacy skills (Reed \& Justice, 2014; Selman, 2017) and do not embrace the responsibility for helping students further develop their literacy skills (Airey \& Larsson, 2018; Gregory \& Colclough, 2018). Perceptions that some students are just not ready for college or are not suited for college are barriers to being more inclusive and equitable with opportunities, particularly for historically under-served populations (Kirst, 2014). Thus, postsecondary faculty members must understand their role in helping all of their students continue developing foundational reading and writing skills.

We consider the attainment of reading and writing skills to be developmental and contextual. Many students may not have had the support, motivation, or optimal instruction to develop aspects of basic literacy skills, and yet they may still seek to pursue a college education (Penrose, 2002; Wallaert, 2018). Faculty members may take actions that exclude students from post-secondary education based on perceptions of the students being ill-prepared for college without considering their and the institution's role in assisting the students (Jansen \& van der Meer, 2012). Some faculty members may perceive students must enter their courses with well-developed literacy skills, and if students do not have the skills, they must acquire the skills due to not being college-ready (Donham, 2014; Jansen \& van der Meer, 2012). Thus, perceptions of poor K-12 literacy preparation may not be considered a gap to be filled, reinforcing the situation as a barrier to equity, access, and inclusion in postsecondary education. Suppose we do not take steps to increase the number of students becoming proficient readers. In that case, the United States will lose a growing and essential proportion of its citizens to poverty, a situation that becomes a burden for all (Feister, 2010). 
Given the importance of addressing literacy issues to enhance equity and inclusion (Ellis \& Rowe, 2020), there is a need for related research. In our search of the literature in multiple scholarly databases, we were unable to find any research reports on the mindsets of postsecondary faculty members associated with their perceptions, expectations, and practices about supporting the development of their students' reading and writing abilities. As we addressed this gap in the literature, we focused on answering the question: What are university faculty members' perceptions and practices for supporting student literacy development to enhance equity? Our research is the first study we are aware of that explicitly assesses faculty members to empirically document their mindset associated with their perceptions, expectation, and practices for teaching their students literacy skills using an equity and inclusion framework. Before delving into our research, we build a case for our study through a literature review.

\subsection{Defining Literacy - Reading and Writing}

To ensure our research on faculty members' mindsets for teaching literacy skills to all students is framed appropriately, we begin our literature review operationally defining literacy. The definition of literacy continues to evolve. Anderson and colleagues (1985) propose the following five guiding principles for defining literacy: (a) reading is a constructive process, (b) reading must be fluent, (c) reading must be strategic, (d) reading requires motivation, and (e) reading is a continuously developing skill. In the decades following, Smagorinsky (2001) revised the term literacy to be more than reading, arguing that literacy is the process of using reading, writing, and oral language to extract, construct, integrate, and critique meaning through interaction and involvement with multimodal texts in the context of socially situated practices. Smagorinsky (2001) applied his definition of literacy to the five guiding principles resulting in (a) literacy is a constructive, integrative, and critical process situated in social practices; (b) fluent reading is shaped by language processes and contexts; (c) literacy is strategic and disciplinary; (d) literacy entails motivation and engagement; and (e) literacy is a continuously developing set of practices. Ruddell and Unrau (2004) claim that literacy expands our thinking by having us (a) ask questions, (b) make connections to background knowledge, (c) rethink perspectives based on interactions with texts, and (d) step out, analyze, and assess text. Similarly, the International Literacy Association (2020) defines literacy as "[t]he ability to identify, understand, interpret, create, compute, and communicate using visual, audible, and digital materials across disciplines and in any context" (para. 1)

Other entities, (i.e., Organization for Economic Cooperation and Development, 2006), recognize reading literacy as "an individual's capacity to understand, use and reflect on written texts, in order to achieve one's goals, to develop one's knowledge and potential and to participate in society" based on the belief that "literacy enables the fulfillment of individual aspirations" (p. 46). Similarly, Keefe and Copeland (2011) encouraged researchers to expand their definitions of literacy beyond being a skill-centered definition to a more transactional (Rosenblatt, 1994) and empowering (Appleton et al., 2008; Tatum, 2008) point-of-view. Frankel et al. (2016) argue that the definition of literacy should also include consideration of values, beliefs, and power interactions such as those related to language, gender, ethnicity, and religion.

We embraced the more progressive definition of reading and literacy as we considered how faculty members engage in activities to address their students constrained literacy skills. Further, we maintain that the progressive definition of literacy is aligned with an education equity mindset. Given the evolving definition of literacy, there is justification for examining how faculty members engage in teaching and supporting their students' literacy development.

\subsection{Content Literacy}

Content literacy generally refers to implementing various stand-alone strategies to help students understand text in subject-matter courses (Shanahan \& Shanahan, 2012). In their review of the literature, Hinton and Suh (2019) found that the definition of literacy is expanding to include other subject areas such as the arts and physical education and consideration of digital literacies. The expansion consists of effective engagement with digital textbooks and evaluating digital tools and resources used by experts and practitioners in the discipline field (i.e., biologists, chemists). Hinton and Suh (2019) posit that an expansive view of content literacy can encourage teachers to broaden their perspective to consider digital literacies and expand the pool of disciplines with which to collaborate.

Content literacy is critical in postsecondary education as there is an expectation for students to develop their literacy skills across the curriculum. Yet, as Gregory and Colclough (2018) report, many faculty members do not perceive teaching students content literacy to be part of their role but realize they have to so the students can learn disciplinary content. Thus, there is a warrant for examining the activities that faculty members from various disciplinary content areas engage in to enhance their students' literacy skill development. 


\subsection{Defining Literacy in a College Setting}

Weideman (2014) identifies ten different abilities as crucial to academic literacy, including the abilities to "understand a range of academic vocabulary in context ... make distinctions between essential and non-essential information ... make meaning (e.g. of an academic text) beyond the level of the sentence" (p. v). Yancey (2009) identifies similar skills, including writing for appropriate purposes, gathering and interpreting information, critical thinking, self-evaluating writing, and developing creative works.

More recent scholarship has moved beyond defining academic literacy as a series of skills to define academic literacy as a social practice that involves the reader, the community, and the environment (Holschuh, 2019). There is now recognition that students arrive on college campuses with multiple literacies reflective of their experiences, abilities, motivations, and interests (Pawan \& Honeyford, 2009; Pugh et al., 2000). Pawan and colleagues (2000) argue that multiple literacies should be considered part of, or perhaps in addition to, academic literacy since multiple literacies impact how students approach both readings and discourse. In recognition of the expanded definition of literacy, we embrace the position of Paulson and Armstrong (2010), who suggest academic literacy is multifaceted and should be understood to include reading, learning, and opportunities to address student skills holistically. The holistic consideration of student literacy is aligned with a strong education equity mindset and therefore is critical to assess when examining the literacy mindset of faculty members. Regardless, there is evidence to suggest that many students who enter college have underdeveloped literacy skills (Falk-Ross, 2001), tend not to enjoy reading (Gilbert \& Fister, 2011), but find benefit in efforts to increase their literacy skills (Howard et al., 2018).

\subsection{Faculty Perceptions of Attitudes toward Literacy}

Faculty perceptions and attitudes toward teaching literacy skills are mixed. Because most college faculty have not been prepared in literacy instruction, they are challenged by what they can and should do to help struggling students meet expectations for reading and writing (Gregory \& Colclough 2018). However, as faculty recognize how reading and writing among disciplines can differ, they are also recognizing a need to address issues of literacy instruction for their students (Glotfelter et al., 2020), embracing the notion students are unlikely to learn what is not being taught. Further, Glotfelder and colleagues (2020) recognize that the transfer of literacy from English courses to other disciplines is not likely to lead to students meeting the content reading and writing expectations of the discipline.

Our search of the literature for empirical studies of faculty perceptions of, attitudes toward, and engagement in teaching literacy in their content areas revealed scant research on the topic (Perin, 2013). Of the few studies we found, most focused on faculty members' teaching in K-12 institutions and are somewhat dated (e.g., Dupuis et al., 1979). A rare recent study we located at the postsecondary level by Gregory and Bean (2020) reported engaging community college faculty members in professional development to prepare them to teach literacy in the context of their discipline. Gregory and Bean found the participating faculty members experienced increases in their understanding of literacy and implemented the new practices they learned for teaching literacy and acculturating students into their disciplines. As Perin (2013) argues, there is a substantial lack of empirical studies of the literacy development of college students and, thus, a need for more research in the area.

Placing a focus on reading within a subject matter course such as math, English, science, and social studies is not a new concept (i.e., Barton, 1997; Manzo \& Manzo, 1990). However, most college students receive little or no instruction in content area reading strategies with the exception of teacher preparation programs. Thus, there is a high likelihood that university faculty members have not been prepared to teach content area reading or have even been exposed to the concept.

The importance of literacy development to student success and the lack of empirical studies of preparing faculty to teach literacy reveals a critical gap in the literature. Thus, when considering the literacy-focused educational equity mindset of faculty members, there is justification for assessing their preparation to teach content literacy skills and their knowledge of the science of learning to read and write.

\subsection{University Faculty Member Attitudes and Perceptions - by Content}

According to Gregory (2018), many research studies have found that students enter college with insufficient literacy skills to complete content-specific college-level coursework. However, while content area faculty members have the expertise of their subject content, they are not prepared to integrate literacy into their instruction due to a lack of preparedness from their degree programs (Gregory \& Colclough, 2018). For almost 20 years, multiple research studies have postulated that all subject areas in higher education should share responsibility in literacy growth and development of the students (Elton, 2010; Johns, 1997; and Wingate, 2016), 
but unfortunately, many content area faculty members remain unable or uncommitted to teaching literacy skills.

Within Science, Technology, Engineering, and Mathematics (STEM), faculty commonly believe that writing is valuable for all students but tend to seldom engage their students in writing or teaching writing (Stroumbakis et al., 2010). Moon et al.'s (2018) report of faculty conceptions of writing and the use of writing within their STEM courses revealed a wide range of perceptions of good writing and how to achieve quality writing. As Moon et al. share, "faculty have under conceptualized how to identify good writing, relying on their intuition and tacit knowledge, and that this may contribute to difficulty grading" (p. 1024).

A perspective held by many STEM faculty members is that students can learn a lot about science or mathematics without actually reading the content (Norris \& Phillips, 2003). Learning STEM content without reading overlooks the broad definition of literacy. Yet, if students do not have a fundamental content literacy, they will miss the interconnections, relationships, and implications of the content (Norris \& Phillips, 2003). Thus, addressing content literacy is critical to preparing students to delve into complex concepts and communicate their understanding in ways aligned with the expectations and norms of the discipline.

\subsection{Literacy and Equity}

We recognize that in higher education students are expected to participate in much independent reading in various text structures. Further, we also contend there is an expectation that when students complete their K-12 education, they can comprehend what they read and effectively apply higher-order literacy skills such as analysis, critique, and synthesis of information. Many students are not prepared to meet these challenges and succeed in college (Au \& Raphael, 2000; Gorski \& Swalwell, 2015), so faculty have to help students become literate to ensure educational equity. Literacy-focused educational equity is necessary so all students can become literate, contributing, and productive members of society (Au \& Raphael, 2000). Thus, we argue that faculty members should embrace a strong education equity mindset and maintain a focus on their role in ensuring student success.

\subsection{Literacy Focused Education Equity Mindset}

Through our literature review and ongoing discussions, we determined that postsecondary faculty members' perceptions, expectations, and practices associated with supporting their students' literacy skills development reflect their literacy-focused education equity mindset. Consistent with the recommendation of French (2016), we view a literacy-focused education equity mindset on a spectrum (see Figure 1). We designed the mindset spectrum using the perception that all faculty members have a literacy-focused education equity mindset. However, there is a stark difference between a weak and a strong mindset, as communicated in Figure 1.

A faculty member would be considered to hold a weak literacy-focused education equity mindset if they do not perceive a need to differentiate instruction for their students; perceive student success as the student's responsibility; consider teaching to be content delivery; and ignore issues of equity, inclusion, diversity, and access. In contrast, faculty members are considered to hold a strong literacy-focused education equity mindset if they understand the need to differentiate instruction for their students; perceive faculty members' responsibility for student success; consider teaching to be helping students develop; and embrace issues of equity, inclusion, diversity, and access.
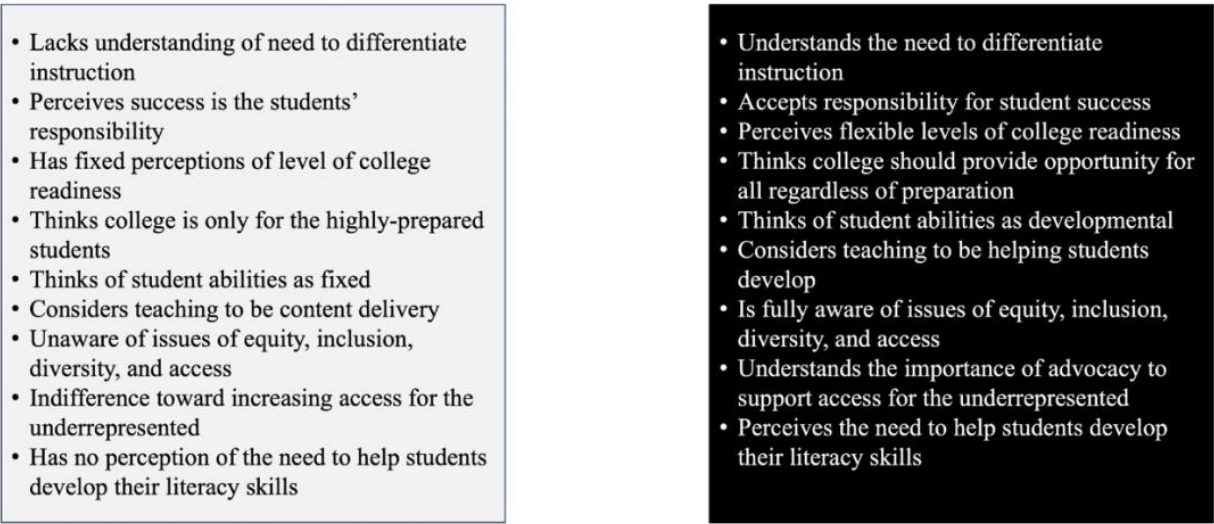

\section{LITERACY FocUSEd EdUCATION EQUITY MINDSET}

Figure 1. Literacy focused education equity mindset spectrum 
To effectively communicate the implications of the mindset, we created a graphic reflective of the expression of actions aligned with elements of a strong literacy-focused education equity mindset (see Figure 2). We argue that the actions of a strong mindset would increase opportunities for college students who struggle with reading, writing, or both to gain the support needed to develop their skills. Thus, we maintain that the inclusive environment created by faculty members with strong mindset actions would address limitations in students' college-level preparation (Greene \& Forster, 2003). The premise for the mindset actions is faculty members engage in practices while meeting their students where they are in their literacy skill development and providing the students with multiple opportunities that support and scaffold their literacy skills growth (Gruenbaum, 2012; Lampi et al., 2019; Perin \& Holschuh, 2019; Theriault et al., 2020).

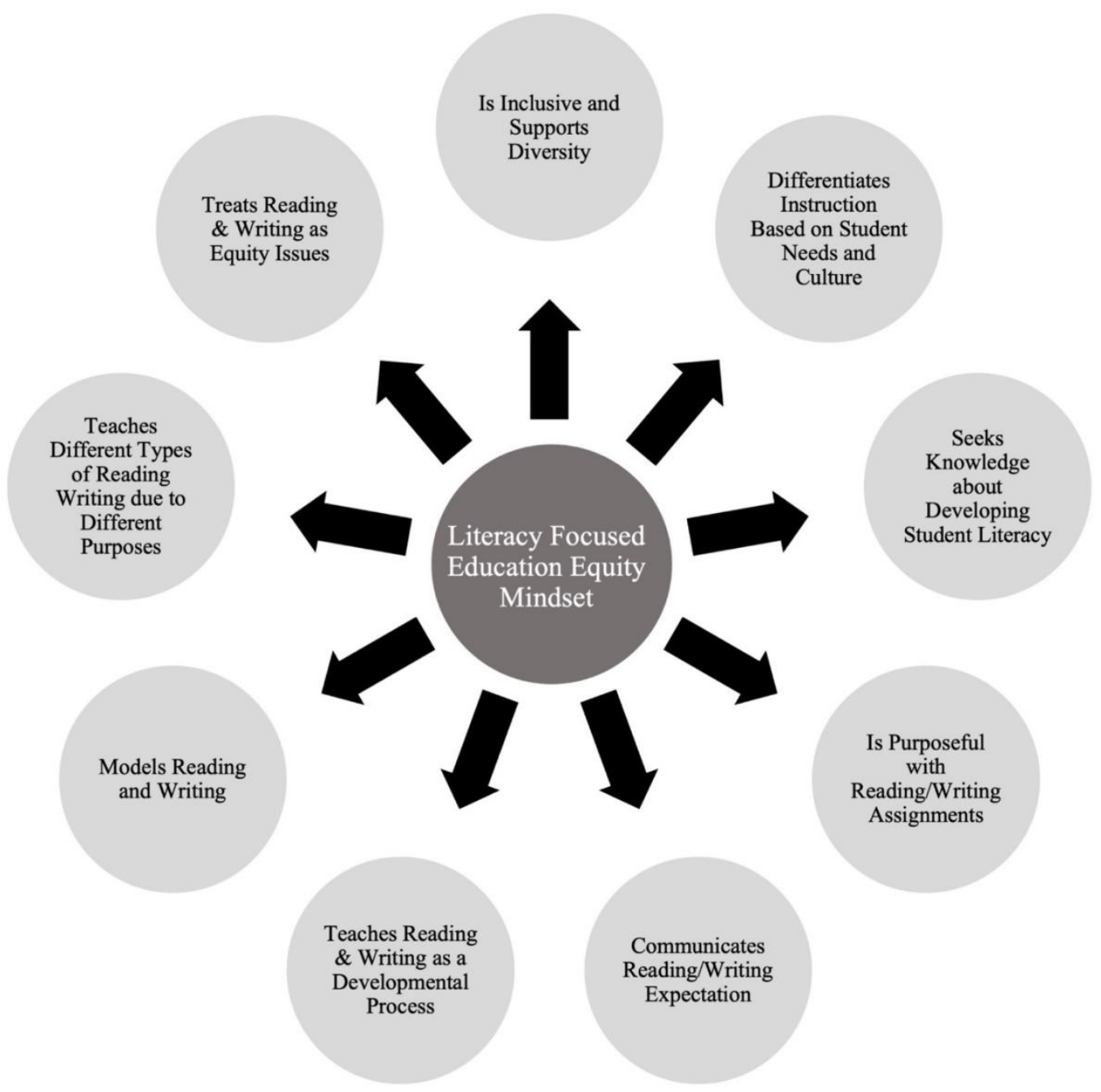

Figure 2. Literacy development actions guided by a strong literacy-focused education equity mindset

\section{Method}

\subsection{Research Question}

Given our perception faculty members must possess a strong education equity mindset and act on that mindset to ensure success for all students, we wanted to gain a deeper understanding of faculty members' perceptions and actions associated with teaching literacy skills to their students. Thus, our overarching research question for our mixed-methods cross-section study was, "What are university faculty members' perceptions and practices for supporting student literacy development to enhance equity?" To answer our primary research question, we developed the following set of guiding research questions to frame our study:

- How prepared are faculty members in reading and writing instruction?

- What are faculty members' perceptions of their responsibilities for developing literate students? 
- What activities do faculty members engage in to enhance their students' literacy?

- What are faculty members' expectations of the literacy levels of their students?

- How are the faculty members' perceptions and practices for teaching literacy related to their perceptions of equity?

- What is the relationship between faculty members' perceptions and practices and personal and professional variables?

\subsection{Participants}

We sent an invitation to participate in our research to 3276 faculty members at institutions in the south-central region of the United States. We had 345 faculty members begin our survey, and of those, 246 completed at least $90 \%$ of the items. The participants were on average 47 years old $(S D=11.22)$ and had worked in higher education for an average of 14.42 years $(S D=9.87)$. There were $40 \%$ who identified as male and $57 \%$ who identified as female, with 3\% identifying as other or preferring not to answer. The majority identified as White (88\%), with 3\% identifying as Black, 3\% identifying as Hispanic, $2.5 \%$ as Asian, .5\% as Native American, and $1.5 \%$ identifying as Other, and $1.5 \%$ declining to provide their ethnicity. There were 81 participants from research universities, 71 from professional doctorate institutions, 50 from masters granting institutions, 39 from a primarily undergraduate institution, and 4 from a community college. Only two participants were from a private institution. The majority taught students on-ground face-to-face (68\%). Additionally, $16 \%$ indicated other as their teaching format, and $8 \%$ each indicated either hybrid or online. Only $9 \%$ indicated they taught remedial courses, with $91 \%$ indicating they did not teach remedial courses. Thirty-two percent of the participants taught both undergraduate and graduate students, $27 \%$ taught lower- and upper-division undergraduate students, $18 \%$ taught only graduate students, 9\% taught all upper-division undergraduate students, $7 \%$ taught only lower-division undergraduate, and $7 \%$ taught students at all levels. We present the distribution of the participants' primary disciplines in Figure 3.

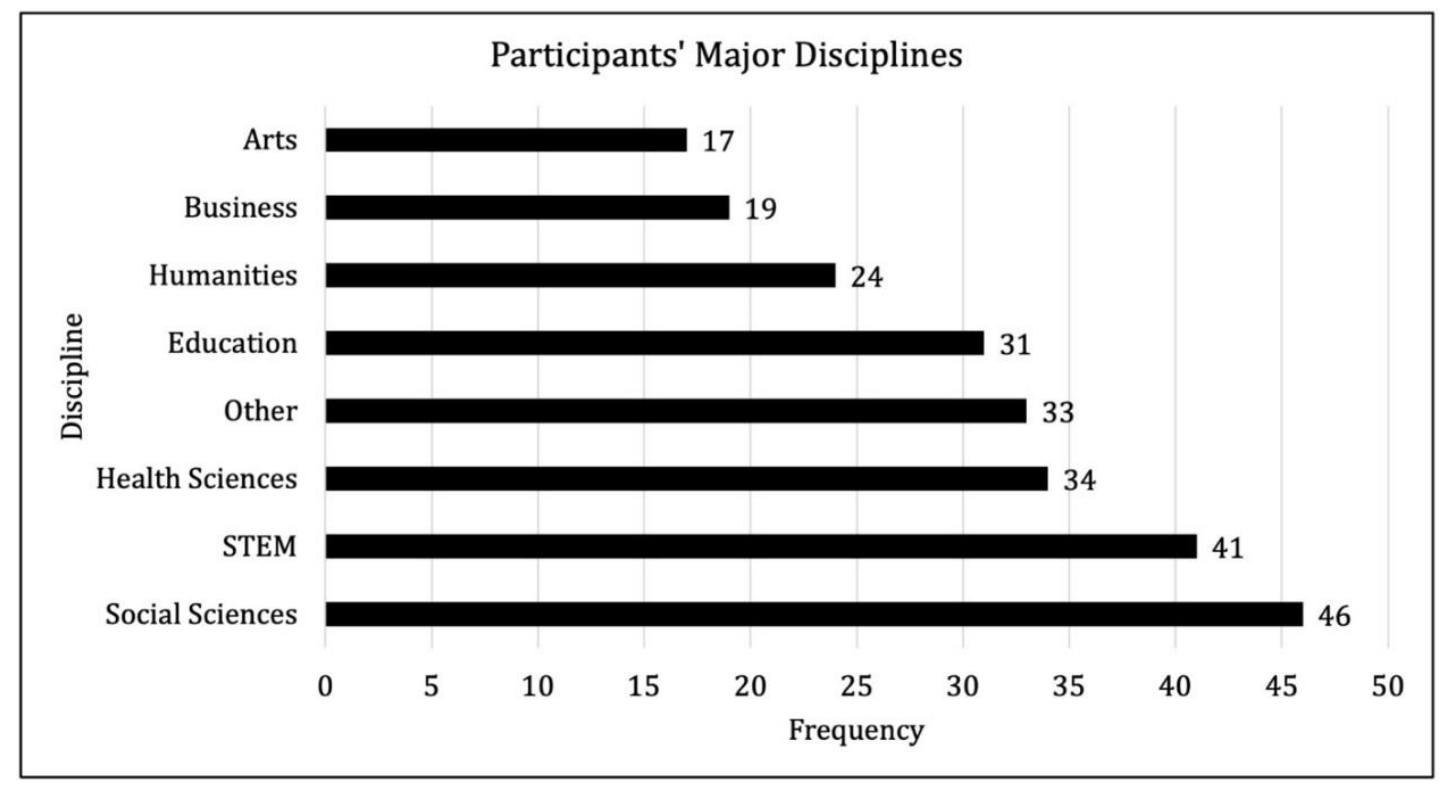

Figure 3. Distribution of participants by their primary disciplines

\subsection{Study Design}

We engaged in survey research using a cross-sectional research design. We used the surveys to gather data from many participants distributed over a region in the southern United States. Our cross-sectional design allowed us to collect data at a single point in time to determine the current status of the literacy-focused equity mindset of university faculty members. We adopted a mixed-methods design to enhance our opportunity to gather the data needed to understand and empirically document faculty members' literacy-focused equity mindset.

\subsection{Survey Development}

Given the exploratory nature of our research, we could not locate any extant surveys designed to assess faculty 
members' perceptions, expectations, and practices for teaching their students literacy skills, particularly through the lens of equity and inclusion. Therefore, we determined it was necessary to develop an instrument. We began development by considering the equity and inclusion perceptions and actions associated with supporting student literacy development as shared in our model of a faculty member's literacy development mindset (see Figure 2). We reflected on our work with first-year college students and college students who struggle with literacy and faculty members who are supportive and unsupportive of student literacy development. We also considered the scant research on improving college students' literacy skills, such as the work of Gruenbaum (2012), Lampi et al. (2019), Perin and Holschuh (2019), and Theriault et al. (2020). We developed multiple selected and free-response items for each facet of our mindset model. As a team, we reviewed the items, combined redundant items, removed items that were distal to our research focus, and edited items that deviated slightly from our mindset facets. We then developed a survey of the revised items.

We began validating our survey with each team member independently reviewing each item and aligning the item to the representative mindset element. We then collectively reviewed the compiled results of our alignment exercise. We resolved discrepancies through discussion resulting in either editing the item for clarity or eliminating the item from the survey. Following our internal validation process, we shared our survey with seven scholars researching issues of postsecondary equity. We asked the scholars to share how much they felt each item aligned with our mindset elements and to what extent each item represented issues of equity and inclusion.

We reviewed the feedback of the scholars and made additional adjustments to our survey to assure item validity and construct representation. Our final survey contained 28 selected-response items, three free-response items, and two sliding bar items. We used a Likert scale for responding to the selected response items and an eleven-point scale ranging from " 0 " to " 10 " for the sliding response items. The selected-response items included stems such as "I am willing to teach any student regardless of reading ability" and some negatively phrased items such as "Teaching students how to read text is not part of my responsibilities." Our free-response items included prompts such as "How do you support your students struggling with their reading and writing skills?" The slider item stems included "Rate the student's responsibility for addressing limitations in their reading skills. (No responsibility $=0$, Some responsibility $=5$, Complete responsibility $=10$ )." Given the combination of 10-point scale items, Likert scale items and, free-response items, we did not think an exploratory factor analysis would be an effective measure of instrument reliability. Therefore, we calculated the reliability of our Likert scale survey items using Cronbach's alpha which resulted in a value of .87, which indicates an acceptable level of internal consistency for the items.

\subsection{Data Collection}

Our data collection took place online using Qualtrics, a web-based survey site. We gathered the publicly accessible email addresses of faculty members working in universities located in the south-central region of the United States from the institutions' websites. We emailed the faculty members an invitation to participate in our research, including a link to our survey. We gathered data over four weeks. We directly invited a total of 3276 university faculty members from nine institutions to complete our survey. We also asked those we invited to share the email invitation with other faculty members. Thus, we likely had participants from institutions other than those we targeted for our data collection. We did not collect the names of the institutions to maintain anonymity for our participants.

Given the nature of our study, survey research, we anticipated between a 5\% and $10 \%$ response rate (Delighted, LLC, 2021) as we offered no incentives or conducted additional follow-up requests. The final response rate was $7.5 \%$, which we deemed reasonable given the low interest of many faculty members in completing surveys and teaching content literacy to their students.

\subsection{Analysis}

Quantitative data. Following data collection, we downloaded our dataset to a spreadsheet. We began our data conditioning by removing the responses of those participants who did not complete at least $90 \%$ of the free-response items of the survey. We also assured the free-response quantitative items did not contain qualitative data (e.g., "5 years" entered for years teaching changed to " 5 "). We then imported the data into a statistical processing package, SPSS, for further conditioning. We used the software to replace the missing values of the occasional skipped response with the series mean. Once we conditioned the data, we calculated the descriptive statistics for all free-response items, reverse coded the responses to the negatively stated items, and calculated the composite scores for our attributes. We completed our analysis by calculating multiple inferential statistics.

Qualitative data. Before analyzing the qualitative data, we developed a set of codes aligned to each of our primary postsecondary faculty literacy-focused equity mindset attributes (see Table 1). Our codes represent both 
a strong and a weak mindset (denoted with a "W" in Table 1). In developing the codes, we relied on our knowledge from our prior research in education equity, our experience as postsecondary faculty members formally engaging in work to make the institution more inclusive, and our knowledge gained through our literature review. We then applied the codes by collectively coding the first 20 qualitative items for each of the three free-response items. Following our initial coding, we collectively reviewed the coded data for alignment with the corresponding education equity attribute. For the responses in which our codes were not the same, we discussed our thought processes and interpretation until we agreed on the proper codes. We then proceeded by dividing the remaining data into sections and assigned them to pairs of researchers on our team. In our pairs, we independently coded the same subset of the items, compared our codes, and resolved any variations in the codes for the data to achieve analysis consistency.

Table 1. Mindset Attributes and Associated Codes

\begin{tabular}{|c|c|}
\hline $\begin{array}{l}\text { Mindset Attributes and } \\
\text { Abbreviations }\end{array}$ & \\
\hline $\begin{array}{l}\text { Differentiate Instruction } \\
\text { (DI) }\end{array}$ & $\begin{array}{l}\text { Teach all students the same (W), modify assignments based on student needs, } \\
\text { student choice, one-on-one, small groups, varies instruction, changing content and } \\
\text { pace based on student learning, multiple modalities, rigid adherence to the syllabus } \\
\text { (W), no knowledge of student backgrounds (colorblind) (W) }\end{array}$ \\
\hline $\begin{array}{l}\text { Accepts } \\
\text { (SPO) }\end{array}$ & $\begin{array}{l}\text { Requires conferences/office h } \\
\text { grades, not my area }(\mathrm{W}) \text {, referr } \\
\text { of knowledge }(\mathrm{W})\end{array}$ \\
\hline Flexible Perception (FP) & $\begin{array}{l}\text { ts I get, meet students where they are, have to come ready with } \\
\text { should come to college, working in teams to support students, } \\
\text { readiness }\end{array}$ \\
\hline $\begin{array}{l}\text { College Opportunity for } \\
\text { All (CO) }\end{array}$ & $\begin{array}{l}\text { W), some } \\
\text { s) college }\end{array}$ \\
\hline $\begin{array}{l}\text { Recognizes Abilities as } \\
\text { Developmental (RAD) }\end{array}$ & $\begin{array}{l}\text { Learn } \\
\text { the sc } \\
\text { prior }\end{array}$ \\
\hline $\begin{array}{lcr}\text { Teaching } & \text { is } & \text { Helping } \\
\text { Students } & \text { to } & \text { Develop } \\
\text { (THSD) } & & \end{array}$ & $\begin{array}{l}\text { My job is to provide information (W), mentor, support, scaffolding, reaching out to } \\
\text { students in need, I have office hours (W), meaningful feedback, flexible } \\
\text { assignments, adjusting grading, formative and summative assessments, } \\
\text { non-meaningful feedback (W), using university resources (S or W) }\end{array}$ \\
\hline $\begin{array}{l}\text { Embraces } \quad \text { Issues of } \\
\text { Equity, } \quad \text { Inclusion, } \\
\text { Diversity, Access (EIDA) }\end{array}$ & $\begin{array}{l}\text { Recognizes cultural differences, understanding differences in background, } \\
\text { treat/teach all students the same (W), provide opportunity for all, differentiation, } \\
\text { colorblind }(\mathrm{W}) \text {, stereotype }(\mathrm{W}) \text {, }\end{array}$ \\
\hline $\begin{array}{l}\text { Advocacy - to Support } \\
\text { Success } \\
\text { Underrepresented (A) }\end{array}$ & $\begin{array}{l}\text { Work to provide opportunities for others, lower institutional barriers, seek/provide } \\
\text { resources, let the administration take care of it (W), have conversations with } \\
\text { colleagues to raise their awareness }\end{array}$ \\
\hline $\begin{array}{l}\text { Commitment to Helping } \\
\text { Students Develop Literacy } \\
\text { Skills (CHS) }\end{array}$ & $\begin{array}{l}\text { Students should come reading/writing ready (W), I don't teach reading/writing, I } \\
\text { teach my students how to read/write professionally, constructive feedback, refer to } \\
\text { other university resources ( } \mathrm{S} \text { or W), flexibility in reading/writing assignments, } \\
\text { adjusting reading/writing assignments to student needs, making modifications in } \\
\text { reading/writing assignments }\end{array}$ \\
\hline
\end{tabular}

\section{Results}

\subsection{Preparation and Knowledge of Teaching Reading and Writing}

Our first guiding research question asked, "How prepared are faculty members in reading and writing instruction?" To answer this question, we examined the mean and median of individual items and the composite score for our items aligned with professional preparation and knowledge of teaching reading and writing (See Table 2). We found the participants tended to agree $(M d n=4.00)$ they were prepared to teach content area writing but were unprepared to teach content area reading. The participants indicated they agreed $(M d n=4.00)$ they sought out opportunities to learn to teach content writing.

The participants were neutral $(M d n=3.00)$ toward assessing their students' writing skills, studying how to teach 
writing in their content areas, and being unfamiliar with the research on teaching writing. The faculty members disagreed $(M d n=2.00)$ on being familiar with the research on teaching content reading and being prepared to help students who lack reading skills. The composite score for knowledge and preparation for teaching content reading and writing was near neutral $(M d n=3.12)$, indicating a moderate level of preparation and knowledge.

The participants responded to our 10-point slider item asking them to rate their knowledge of the research on teaching reading below moderate $(M=3.56, S D=2.79, M d n=3.00)$. The result indicates that the participants acknowledged that they lacked knowledge of the research on teaching reading.

Table 2. Mean, Standard Deviation and Median for Items Aligned with Knowledge and Preparation to Teach Reading and Writing

\begin{tabular}{lll}
\hline Item & Mean (SD) & Median \\
\hline I am prepared to teach content area writing in my course. & $3.77(.93)$ & 4.00 \\
I am unprepared to teach content area reading in my course. & $3.48(1.10)$ & 4.00 \\
I seek opportunities to learn how to teach my students content writing. & $3.45(1.06)$ & 4.00 \\
I do not know how to effectively assess my students' reading skills. & $3.21(1.11)$ & 3.00 \\
I have studied how to teach writing in my content area. & $3.08(1.26)$ & 3.00 \\
I am unfamiliar with the research on teaching content writing. & $2.92(1.17)$ & 3.00 \\
I have been prepared to help students who lack reading skills. & $2.62(1.09)$ & 2.00 \\
I am familiar with the research on teaching content reading. & $2.44(1.02)$ & 2.00 \\
Preparation and Knowledge of Teaching Reading and Writing Composite Score & $3.12(.72)$ & 3.12 \\
\hline
\end{tabular}

\subsection{Perceptions of Responsibility}

Our second guiding research question asked, "What are faculty members' perceptions of their responsibilities for developing literate students?" To answer this question, we examined the survey items aligned with faculty members taking responsibility for teaching reading and writing and helping students to develop their literacy skills (see Table 3). We found the participants tended to agree $(M d n=4.00)$ they rely on other faculty to teach writing, do not see the need to communicate college-level writing expectations, and do not have time to help students develop their writing skills. The faculty members were neutral $(M d n=3.00)$ toward teaching how to read being part of their responsibilities. The participants disagreed $(M d n=2.00)$ that they get frustrated when students do not write well, and they expected students to come prepared for content reading. Overall, the participants rated (on a 10-point sliding scale) their students' responsibility for addressing limitations in their reading skills as moderately high $(M=7.03, S D=1.66, M d n=7.00)$. Overall, the results suggest that faculty members assume a moderately low level of responsibility for teaching their students to read and write.

Table 3. Mean, Standard Deviation and Median for Items Aligned with Faculty Member Responsibility for Teaching Reading and Writing

\begin{tabular}{lll}
\hline Item & M (SD) & Median \\
\hline I rely on other faculty to teach my students to write so I don't have to. & $3.67(1.08)$ & 4.00 \\
I should not have to communicate college level & $3.47(1.14)$ & 4.00 \\
writing expectations in my course materials. & & \\
I do not have time to help students to develop their writing skills. & $3.36(1.15)$ & 4.00 \\
Teaching students how to read text is not part of my responsibilities. & $3.18(1.22)$ & 3.00 \\
I get frustrated when my students don't write well. & $2.43(.95)$ & 2.00 \\
I expect my students to come to my course prepared for content reading. & $2.24(.82)$ & 2.00 \\
Responsibility for Teaching Reading and Writing composite score & $3.06(.71)$ & 3.00 \\
\hline
\end{tabular}

\subsection{Literacy Instruction}

Our third guiding research question asked, "What activities do faculty members engage in to enhance their students' literacy?" To answer this question, we examined the participants' responses to our items aligned with reading and writing instruction (see Table 4$)$. We found participants agreed $(M d n=4.00)$ to recommending their students take notes as they read, being willing to teach students regardless of their reading abilities, and providing their students with examples of what they consider to be quality academic writing. The participants were neutral $(M d n=3.00)$ toward demonstrating to students how to read texts, choosing reading material with students in mind, writing with students to model academic writing, and integrating reading instruction into content assignments. The overall composite score for instruction $(M=3.44, S D=.56, M d n=3.42)$ indicates a 
high-moderate level of reading and writing instruction. Our results suggest that the faculty members engaged in a high-moderate level of reading and writing instruction with their students.

Table 4. Mean, Standard Deviation and Median for Items Aligned with Faculty Member Reading and Writing Instruction

\begin{tabular}{lll}
\hline Item & M (SD) & Median \\
\hline I recommend students take notes as they read. & $4.14(.80)$ & 4.00 \\
I am willing to teach any student regardless of reading ability. & $3.92(1.01)$ & 4.00 \\
I provide examples of what I consider quality academic writing to my students. & $3.84(1.01)$ & 4.00 \\
I demonstrate how students should be reading texts. & $3.17(1.13$ & 3.00 \\
I choose reading material with students' varying abilities in mind. & $3.13(1.12)$ & 3.00 \\
I write with my students to model academic writing. & $3.08(1.07)$ & 3.00 \\
I integrate reading instruction into my content-focused assignments. & $2.80(1.12)$ & 3.00 \\
Read and Writing Instruction composite score & $3.44(.56)$ & 3.42 \\
\hline
\end{tabular}

We continued our analysis by examining the outcome of our coding of the item asking faculty members to share how they support students struggling with reading and writing. In our analysis, we found a trend in which the weak equity mindset answers paralleled the strong equity mindset answers in frequency, with positive answers occurring with greater frequency than negative responses (see Figure 4). The participants' responses indicated a focus on accepting responsibility for student learning (SPO), a commitment to helping students develop literacy skills (CHS), and a belief that teaching is helping students develop (THSD). There was almost no focus on college being an opportunity for all (CO) and embracing issues of diversity and inclusion (EID). Overall, our results indicate that some faculty members accept responsibility for students struggling to learn and others do not. Overall, the faculty members did not perceive students' struggling with literacy skills as an equity issue.

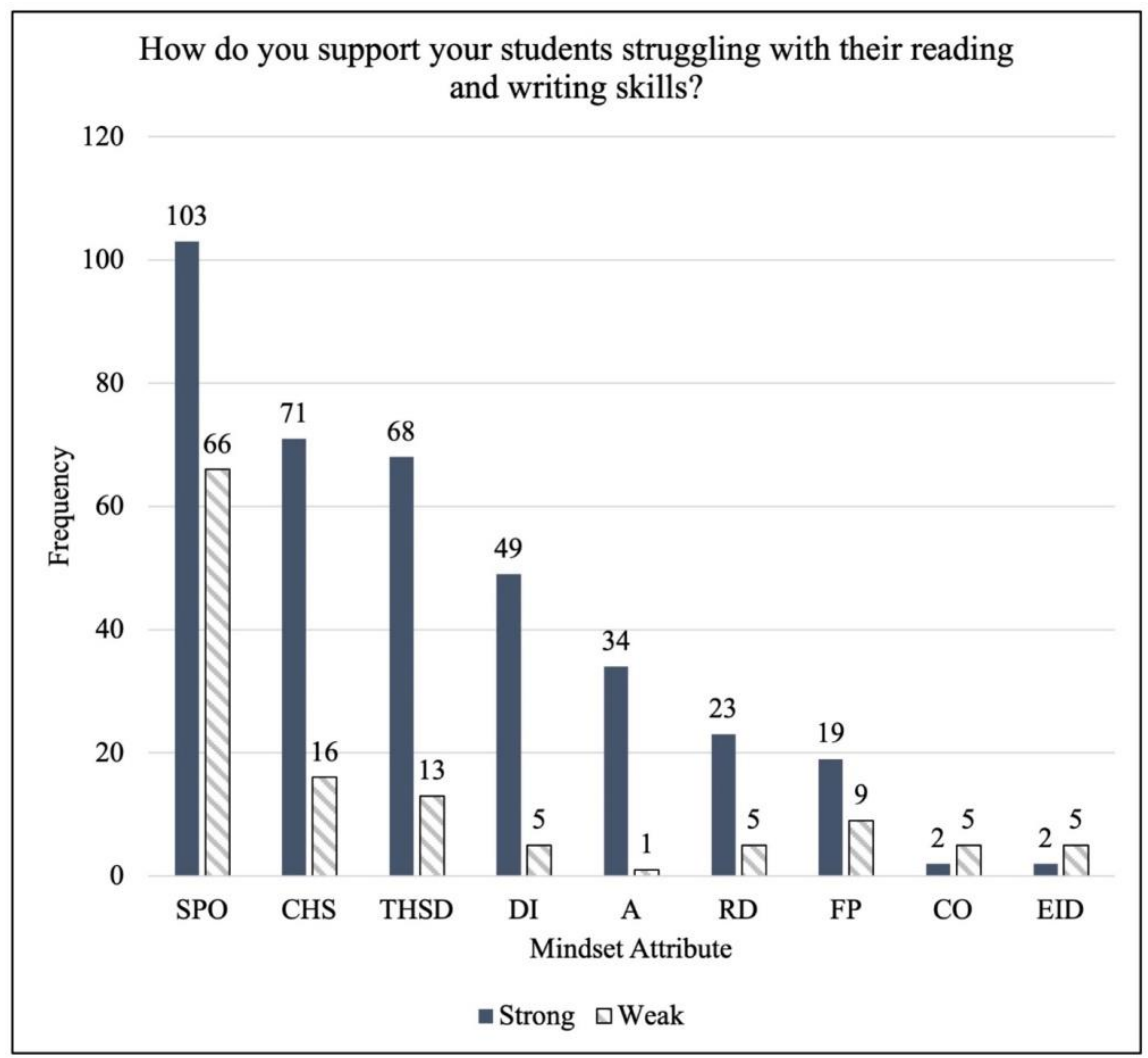

Figure 4. Frequency strong and weak equity mindset coded responses for supporting struggling learners

In Table 5, we provide representative responses to our item asking the participants how they support students who struggle with reading and writing. The responses are paired representative statements aligned with both strong and weak education equity mindsets. 
Table 5. Strong and Weak Equity Mindset Representative Responses to Supporting Students Struggling with Reading and Writing

\begin{tabular}{|c|c|}
\hline \multirow{2}{*}{$\begin{array}{l}\text { Mindset Attribute } \\
\text { Differentiate Instruction (DI) }\end{array}$} & Strong (S) \& Weak (W) Mindset Representative Statements \\
\hline & $\begin{array}{l}\text { S - Multiple skill-building assignments/exercises; one-on-one iterative } \\
\text { editing sessions for those who truly struggle. } \\
\text { W - I do make my assignments difficult enough that they will have to learn } \\
\text { how to read and write, otherwise they will not do well in the course. }\end{array}$ \\
\hline Accepts Responsibility (SPO) & $\begin{array}{l}\text { S- I am willing to coach them with the material if they will come to the } \\
\text { office for additional instruction. } \\
\text { W - We have a writing center on campus. }\end{array}$ \\
\hline Flexible Perception (FP) & $\begin{array}{l}\text { S - Suggesting they listen to books on tape. } \\
\text { W - I assign them a lot of reading and writing assignments. }\end{array}$ \\
\hline College Opportunity for All (CO) & $\begin{array}{l}\text { S - I always try to meet students "where they are" in terms of writing skill, } \\
\text { and I do not guilt students for their weak writing. } \\
\text { W - I do make my assignments difficult enough that they will have to learn } \\
\text { how to read and write, otherwise they will not do well in the course. }\end{array}$ \\
\hline Recognizes & en they fall short. \\
\hline & $\begin{array}{l}\text { W - I have not had a student reveal a reading problem, although they may } \\
\text { exist. }\end{array}$ \\
\hline $\begin{array}{l}\text { Teaching is Helping Students to } \\
\text { Develop (THSD) }\end{array}$ & $\begin{array}{l}\text { S - I'm a proponent of close reading strategies, annotation, etc. and } \\
\text { demonstrating how these skills work in improving reading as well as } \\
\text { reading like a writer. } \\
\text { W - Aside from short meetings outside of class time, I don't do much. }\end{array}$ \\
\hline $\begin{array}{l}\text { Embraces Issues of Equity, } \\
\text { Inclusion, Diversity, Access (EID) }\end{array}$ & $\begin{array}{l}\text { S - Many are internationals. A different level of proficiency must be } \\
\text { tolerated/accepted } \\
\text { W - When papers are graded, I take a few minutes at the beginning of the } \\
\text { next class and give corrections to all without naming which papers these } \\
\text { mistakes were made. }\end{array}$ \\
\hline $\begin{array}{l}\text { Advocacy - to Support Access for } \\
\text { Underrepresented Students (A) }\end{array}$ & $\begin{array}{l}\text { S - Talk with them individually to be sure they are clear on } \\
\text { instructions/info. } \\
\text { W - Point them to campus resources (writing lab, etc.), encourage } \\
\text { supplemental book resources, report struggling students to campus services }\end{array}$ \\
\hline $\begin{array}{l}\text { Commitment to Helping Students } \\
\text { Develop Literacy Skills (CHS) }\end{array}$ & $\begin{array}{l}\text { S - I offer one-on-one assistance and go over tips in class. } \\
\text { W - Send them to the writing/reading center. }\end{array}$ \\
\hline
\end{tabular}

\subsection{Literacy Expectations}

Our fourth guiding research question asked, "What are faculty members' expectations of the literacy levels of their students?" We began answering this question by examining the means, standard deviations, and medians of our items aligned to faculty expectations for students reading and writing skills (see Table 6). We found the faculty members strongly agreed $(M d n=5.00)$ that they could predict a student's reading ability based on their demographics. The participants agreed $(M d n=4.00)$ that they put forth extra effort to help students who struggle with writing and also recognized students were likely to fail their course if they couldn't write well. The participants were neutral toward a belief that students have to write at a college level before enrolling in their course and a belief that they put forth extra effort to support students who struggle with reading. The faculty members disagreed $(M d n=2.00)$ with students being unsuccessful in their courses if they did not read well and holding the expectation that their students must come into their course being able to read at the college level. The composite score $(M=3.20, S D=.52, M d n=3.14)$ for the faculty's positive expectations of student reading and writing skills indicates a moderate level of student reading and writing skills. 
Table 6. Mean, Standard Deviation, and Median for Items Aligned with Faculty Expectations of Their Students' Reading and Writing Skills

\begin{tabular}{lll}
\hline Item & M (SD) & Median \\
\hline I can predict a student's reading ability based on their demographics. & $4.37(.80)$ & 5.00 \\
I put extra effort forth to help students who struggle with writing. & $3.85(1.00)$ & 4.00 \\
If my students cannot write well they are likely to fail my class. & $3.43(.96)$ & 4.00 \\
I put forth extra effort to help students who struggle with reading. & $3.14(1.00)$ & 3.00 \\
Before my students enroll in my class they must be able to write at a college level. & $2.95(1.12)$ & 3.00 \\
Students who have low reading skills will be unsuccessful in my course. & $2.71(1.04)$ & 2.00 \\
I expect that college students can read at the college-level. & $1.96(.94)$ & 2.00 \\
Expectations for Reading and Writing Composite Score & $3.20(.52)$ & 3.14 \\
\hline
\end{tabular}

We continued our analysis by examining the responses to our open-response item asking the participants, "What are your expectations for your students' ability to write, and why is this your expectation?" Again, we analyzed our data using the codes detailed in Table 1 . Our analysis revealed the faculty members tended to respond from a weak equity mindset perspective more frequently than a strong equity mindset perspective (see Figure 5). For example, we found 29 strong mindset responses aligned with the flexible perception element and 76 weak mindset responses - almost three times as many negative responses than positive responses. Overall, the faculty members conveyed a weak education equity mindset in their students' writing ability expectations.

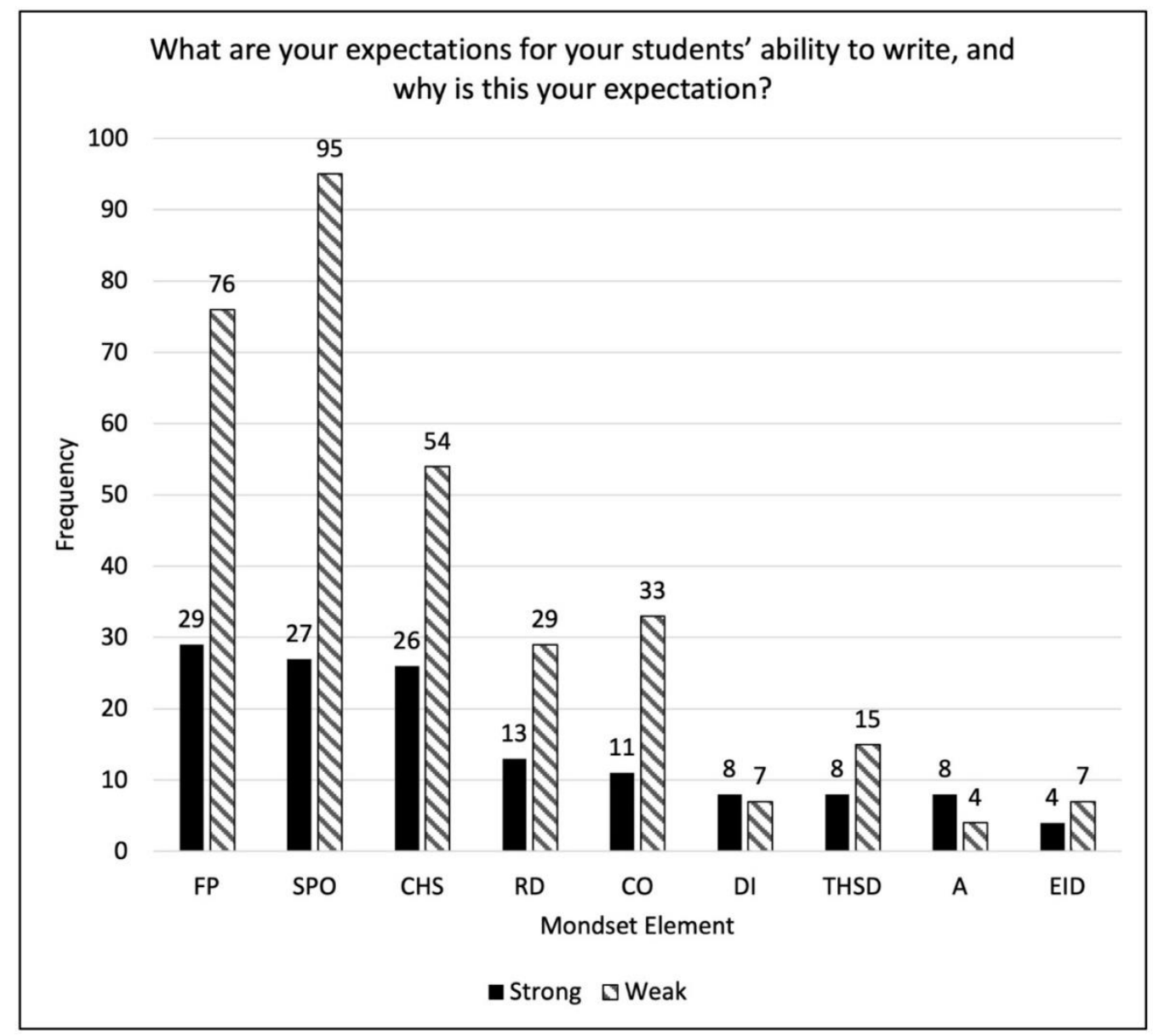

Figure 5. Frequency of the responses to student writing expectations by strong and weak mindset

In Table 7, we provide representative responses to our item, asking the participants their expectations for their students' ability to write and explain their expectations. Similar to Table 5, the responses are paired representative statements aligned with both strong and weak education equity mindsets. 
Table 7. Strong and Weak Equity Mindset Representative Responses for Expectations of Student Writing Ability \begin{tabular}{ll}
\hline Mindset Attributes & Strong (S) \& Weak (W) Mindset Representative Statements \\
\hline Differentiate Instruction (DI) & $\begin{array}{l}\text { S - I have different expectations for undergrad versus grad. I very much } \\
\text { support our undergrads writing as many of our students are first-generation }\end{array}$
\end{tabular} college students.

$\mathrm{W}$ - It is frustrating to have to teach fundamental writing skills to college students.

Accepts Responsibility (SPO) S - I expect them to be able to write but will help the if they're behind the curve.

W - I teach junior/senior STEM courses; students should at that point in their undergraduate studies know how to write clearly.

Flexible Perception (FP)

$\mathrm{S}$ - In the last 5-7 years, incoming freshmen have had serious deficiencies in their writing skills. At that point, I begin instruction, offer tutoring on campus, and grade carefully.

W- I expect a basic level of literacy - let's say high school A or B student level

College Opportunity for All S - I expect students in college to read and write at a college level, but also (CO) realize this varies by the individual student.

W - I expect my students to be able to read and write at a university level because I teach in a university. If they can't perform at that level they shouldn't be here.

Recognizes Abilities as S - For undergraduates in our remedial courses, my expectations are high, but I Developmental (RD) have to do more to support those students.

W - Students will have had ENG comp I and II before I have them in class.

Teaching is Helping Students to Develop (THSD)

S - I expect students to come with varying abilities because we have many students from rural, impoverished schools.

W - Sadly, I expect them to be able to write .... or at least I did when I began teaching.

Embraces Issues of Equity, S - I view typical standards of grammar / syntax / etc. as a form of colonialism Inclusion, Diversity, Access and often work to de-emphasize those issues in relation to matters of (EID)

Advocacy - to Support Access for Underrepresented Students (A)

Commitment to Helping Students Develop Literacy Skills (CHS) organization, context, etc.

W - NO good reason for a college student to begin college and lack those basic skills in reading \& writing.

S - Students admitted to my institution are tested. Those lacking adequate skills are placed in remediation classes, paying full price, yet earning no credit hours. What is the hurdle rate for passing remediation? The graduation rates speaks for itself.

W - I expect students to be able to communicate what they know in an organized manner that is free of grammar and spelling errors.

$\mathrm{S}$ - I expect complete sentences, pretty good punctuation, and staying on topic. I am not surprised when the students don't use paragraph breaks or forget to finish a thought. When you talk to them, they find writing very intimidating. $\mathrm{W}$ - Until you carve out the time and money to support us, we cannot teach our university students to read in our other classes.

\subsection{Perceptions, Practices, and Educational Equity}

Our fifth guiding research question asked, "How are the faculty members' perceptions and practices for teaching literacy related to education equity?" To answer this question, we examined the frequency of the coded responses to all three of our free-response items (see Figure 6). We found more weak mindset responses $(n=631)$ than strong mindset responses $(n=583)$. There were more weak mindset responses for five attributes and more strong mindset responses for four mindset attributes. Our analysis revealed that the participants overwhelmingly did not consider issues of equity and inclusion in their responses, and the majority of those few that did consider equity issues tended to convey a weak equity mindset $(n=18)$ more than a strong equity mindset $(n=12)$. The data suggest that the faculty members do not engage in perceptions and practices for teaching literacy through a lens of education equity. 


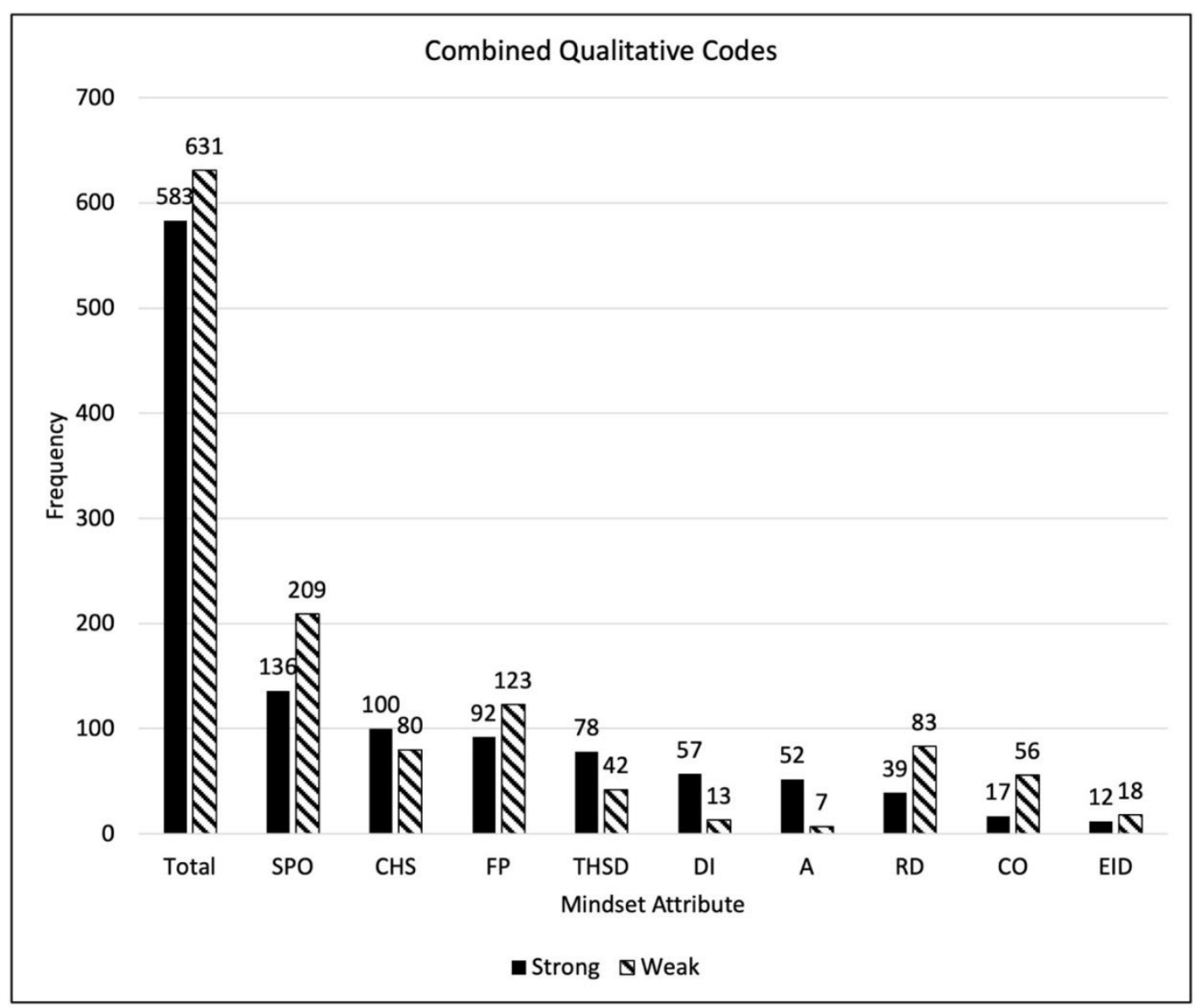

Figure 6. Combined frequency of the strong and weak mindset codes in all qualitative item responses

\subsection{Influence of Personal and Professional Variables}

Our sixth guiding research question asked, "What is the relationship among their perceptions and practices and personal and professional variables?" To answer this question, we calculated a series of descriptive and inferential statistics. We started by calculating the correlations among the composite scores (see Table 8). We found all the composite scores correlated, suggesting that if one area was high, the others were likely high, reflecting a strong literacy equity mindset.

Table 8. Correlations between Composite Variables

\begin{tabular}{llllllll}
\hline Variable & $\mathrm{n}$ & $\mathrm{M}$ & $\mathrm{SD}$ & Expectations & Responsibility & Instruction & Preparation \\
\hline Expectations & 246 & 3.20 & 0.52 & - & & & \\
Responsibility & 246 & 3.06 & 0.71 & $.542^{* *}$ & - & & \\
Instruction & 246 & 3.44 & 0.56 & $.409^{* *}$ & $.461^{* *}$ & - & \\
Preparation & 246 & 3.12 & 0.72 & $.345^{* *}$ & $.509^{* *}$ & $.619^{* *}$ & - \\
\hline .01 &
\end{tabular}

We continued our analysis by calculating the correlations with age, the number of students taught in a semester, and our composite variables. We found age was inversely correlated with responsibility $(r=-.16, p=.019)$ and instruction $(r=-.20, p=.002)$, indicating that age increases faculty members are less likely to take responsibility and engage in instruction that addresses issues of literacy and equity. We also found an inverse relationship between the number of students taught in a semester and taking responsibility $(r=-.21, p=.001)$ which indicates as the number of students taught in a semester increases, taking responsibility for teaching the students literacy decreases.

We then tested for differences between those who taught remedial courses and those who did not. We found those who taught remedial courses had significantly higher scores on the four composite variables (See Table 9). 
The results indicate that those faculty members who taught remedial courses were likely to hold a stronger literacy educational equity mindset than their peers who do not teach remedial classes.

Table 9. Independent Sample t-test between Those Who Teach Remedial Courses and Those Who Do Not Teach Remedial Courses

\begin{tabular}{lllllll}
\hline Variable & Teach Remedial Course & $\mathrm{n}$ & $\mathrm{M}$ & $\mathrm{SD}$ & $\mathrm{t}$ & $\mathrm{p}$ \\
\hline Expectations & Yes & 23 & 3.58 & .59 & 3.83 & $<.001$ \\
& No & 223 & 3.16 & .49 & & \\
Responsibility & Yes & 23 & 3.37 & .82 & 2.20 & .029 \\
& No & 223 & 3.03 & .69 & & \\
Instruction & Yes & 23 & 3.72 & .64 & 2.53 & .012 \\
& No & 223 & 3.41 & .55 & & \\
Preparation & Yes & 23 & 3.63 & .85 & 3.66 & $<.001$ \\
& No & 223 & 3.07 & .68 & & \\
\hline
\end{tabular}

We analyzed the composite scores by gender. We found that females scored higher than males on three composite variables (see Table 10). The results indicate that female faculty members are likely to hold stronger literacy educational equity mindsets than male faculty members.

Table 10. Independent Sample t-test between Males and Females

\begin{tabular}{lllllll}
\hline Variable & Gender & $\mathrm{n}$ & $\mathrm{M}$ & $\mathrm{SD}$ & $\mathrm{t}$ & $\mathrm{p}$ \\
\hline Expectations & Male & 98 & 3.04 & .50 & 4.32 & .000 \\
& Female & 141 & 3.32 & .49 & & \\
Responsibility & Male & 98 & 2.91 & .70 & 2.76 & .006 \\
& Female & 141 & 3.16 & .71 & & \\
Instruction & Male & 98 & 3.31 & .59 & 3.13 & .002 \\
& Female & 141 & 3.54 & .53 & & \\
Preparation & Male & 98 & 3.02 & .67 & 1.82 & .071 \\
& Female & 141 & 3.19 & .73 & & \\
\hline
\end{tabular}

In our analysis by discipline, we found a difference for positive expectations $(F(7,237)=3.89, p<.001)$ with the post hoc analysis revealing significantly greater positive expectations by faculty members in the humanities than faculty members in the social sciences, business, and health sciences, and we found faculty members in business holding lower positive expectations than faculty members in education and the arts. We found a significant difference by discipline for taking responsibility $(F(7,237)=3.89, p<.001)$, with the post hoc analysis revealing faculty members in the humanities holding higher levels of responsibility than faculty members in all other disciplines, and we found faculty members in business having lower levels of responsibility than faculty members in education and other disciplines. We found a significant difference by discipline for literacy instruction in $(F(7,237)=6.04, p<.001)$, with the post hoc analysis revealing faculty members in the humanities holding higher levels of responsibility than faculty members in all other disciplines, and we found faculty members in business holding lower engagement in instruction than faculty members in education, arts, and health sciences. We found a significant difference by discipline for preparation $(F(7,237)=5.82, p<.001)$, with the post hoc analysis revealing faculty members in the humanities holding higher levels of preparation than faculty members in all other disciplines except arts. We found faculty members in business holding lower levels of preparation than faculty members in the arts.

We found one more difference by level of students for expectations for student literacy $(F[6,239]=2.32, p$ $=.034$ ). The post hoc analysis revealed that faculty members who teach all lower-division undergraduate students held higher expectations than faculty members who primarily taught graduate students.

Our analysis failed to reveal differences by type of institution.

\section{Discussion}

The potential for literacy issues to limit a student's achievement in college led us to consider continued instruction in reading and writing past high school as an issue of educational equity. We perceive learning to read and write as a developmental process that takes support and practice that extends into postsecondary education. The support is particularly critical for content literacy. Students with constrained literacy skills who do not receive support are more likely to drop out of school (James \& Okpala, 2010). Thus, it is critical that all 
postsecondary faculty members approach teaching reading and writing as an issue of education equity. The connection between literacy and equity motivated us to empirically document the literacy and equity mindset of faculty members working at post-secondary institutions.

\subsection{Preparation and Knowledge of Teaching Reading and Writing}

Our exploration of faculty members' knowledge of and preparation to teach reading and writing revealed moderate levels of knowledge and modest levels of preparation. We speculate that most faculty members did not receive additional support for reading and writing and have forgotten how novice learners think and what they need to be successful (Nathan, Koedinger, \& Alibali, 2001). The implication for their academic success is a lack of awareness of the need to understand how people learn to read and write to help their students continue developing their literacy skills. A second implication for the lack of awareness is the potential to inadvertently marginalize students who require additional support. We recommend that leadership at colleges and universities consider professional development for faculty members to prepare them with the knowledge and skills needed to effectively support student literacy development.

\subsection{Perceptions of Responsibility}

Our data indicated that the faculty members held a moderate level of responsibility for teaching their students literacy skills. We speculate that the moderate level of responsibility is likely to be associated with their knowledge and preparedness, as the faculty members indicated they defer to others to teach these skills, which is consistent with the work of Gregory and Colclough (2018). The implications for deferring to others and not taking responsibility is the potential for faculty members to not provide the instruction students need to be successful readers and writers within specific content areas or disciplines, as reported by Gruenbaum (2012). Another ramification for modest levels of assuming responsibility for teaching students' literacy skills is the potential for not teaching the whole student, leaving students with gaps in their knowledge due to a lack of focus on essential skills needed to learn content. We recommend adopting initiatives to raise faculty members' awareness of the importance of addressing student learning and literacy skills as part of assuring the students are prepared to and supported in learning the targeted content.

\subsection{Literacy Instruction}

We found the participants tended to engage in some form of literacy instruction. We posit the faculty members were pressured into engaging in these practices due to the substantial limitations in student content learning without the additional support. We considered there to be a paradox due to faculty members' lacking knowledge and preparation to teach literacy and, yet they are engaging in literacy instruction. An implication for engaging in literacy instruction without formal preparation is the potential to use ineffective or inefficient instructional methods (Hoeft, 2012). The instructional approaches of the faculty members may work well for some students and be ineffective for others, potentially creating a more significant divide between those who need little support and those who need substantial support contributing to an additional issue of education equity. We recommend professional development for faculty members to ensure they are using evidence-based practices in their approaches to supporting student literacy development.

\subsection{Literacy Expectations}

Similar to our other findings, we found the faculty members held moderate levels of positive expectations of student literacy skills. Yet, we were deeply concerned to find that the faculty members strongly agreed to being able to predict their students' literacy skill level based on the student's demographics. We were troubled by this finding because it reflects the potential for stereotyping and potential systemic discrimination. Our finding suggests the need to explore further faculty members' perceptions of student literacy in association with the students' demographics. The perception of predicting a student's literacy level based on their demographics could potentially lead to less positive levels of expectations and the possibility that faculty members advise students to consider different academic majors or careers. Regardless of the potential, faculty members' use of demographics to predict their students' literacy is a phenomenon that requires additional research.

\subsection{Perceptions, Practices, and Educational Equity}

We found the faculty members shared a nearly equal mix of strong and weak education equity mindset perspectives. We posit faculty members tend to express different mindsets depending on whether the focus is on their activities or the activities of their students. We found that the faculty members tended to express a weak education equity mindset when considering issues of literacy development from the perspective of student engagement and responsibility. However, the participants expressed a strong education equity mindset when considering their role in addressing issues of student literacy development. The shift in mindset suggests that 
faculty members may not be considering issues of student literacy development from a systemic perspective but rather a personal perspective, which results in deficit thinking when considering literacy in terms of student engagement (Yosso, Smith, Ceja, \& Solórzano, 2009). We maintain the potential engagement in deficit thinking of student capacity, and the lack of a systemic perspective of learning barriers may result in the continued marginalization of those who need ongoing support to develop their literacy skills. We recommend campus leadership consider initiatives that increase faculty members' understanding of the systemic barriers students face that may limit their literacy skill development and how the faculty members could address the barriers and support student learning.

\subsection{Influence of Personal and Professional Variables}

We found several relationships to personal and professional variables, including discipline, gender, and age. Identifying the differences is essential to address issues of literacy and equity with the faculty members who may be in high need of support to increase their awareness of and processes for supporting student literacy development. The differences may also suggest that some disciplines may be less inclusive and supportive of students with constrained literacy skills. Additional research is needed to explain the differences, as our research exposed the differences, but we did not gather sufficient data to explain the differences. We recommend leadership at colleges and universities assess the faculty members' perceptions of supporting literacy development and perceptions of educational equity to provide a baseline for professional development and other interventions to increase the educational equity mindset and commitment to supporting literacy development.

\subsection{Limitations and Future Research}

The first limitation of our study is the potential that our participants were only faculty members who already have a literacy equity mindset. Therefore, our sample may have been biased toward supporting the literacy development of college students and not representative of all faculty members. Although our sample seems diverse and reflects a range of views, future research may need to be conducted to effectively gather data from a greater diversity of faculty members to assure representation of perspectives aligned with the faculty as a whole.

Similarly, the second limitation of our research was the participants we recruited were all from a region of the south-central United States, leading to a potential sampling bias. It may be possible faculty members from other regions of the United States, and the world may think and act differently about teaching literacy and supporting educational equity. Thus, there would be value in replicating our study in the other USA and world regions.

Our third limitation is the nature of our data collection, which was survey-based. It is possible the participants answered in ways that led to a social desirability bias. The survey also did not allow us to confirm the faculty members' actual practices through interviews or observation. Future research might extend beyond the use of surveys to collect data, as we did with our exploratory study, and build on our work by engaging in observations and interviews of faculty members.

Our fourth limitation is our focus on four-year institutions. It may be possible that faculty members at two-year institutions may think and act differently, and therefore hold and display a different literacy and educational equity mindset. Future research might focus exclusively on faculty members at two-year institutions.

\subsection{Conclusion}

Literacy is an issue of education equity. Students may enter postsecondary education with under-developed literacy skills and in need of support to develop those skills. Supporting student literacy learning reflects an understanding of reading and writing as a developmental process and the importance to student success. However, our research indicates that faculty member engagement in supporting student literacy learning is fragmented, reflecting both elements of a weak and strong education equity mindset, shifting based on the person of focus. We have answered our research questions but raised several others. We hope others will build upon our research and continue to explore the education equity mindset of faculty members through the lens of supporting student literacy development.

\section{Acknowledgments}

All co-authors contributed equally to this research and report. We also want to thank the faculty members who completed our survey, and acknowledge our appreciation of their time.

\section{References}

Airey, J., \& Larsson, J. (2018). Developing students' disciplinary literacy? The case of university physics. In S. Tang \& K. Danielsson (Eds.), Global developments in literacy research for science education (pp. 357-376). Springer. https://doi.org/10.1007/978-3-319-69197-8_21 
Anderson, R. C., Hiebert, E. H., Scott, J. A., \& Wilkinson, I. (1985). Becoming a nation of readers. National Institute of Education.

Appleton, J. J., Christenson, S. L., \& Furlong, M. J. (2008). Student engagement with school: Critical, conceptual, and methodological issues of the construct. Psychology in the Schools, 45, 369-386. https://doi.org/10.1002/pits.20303

Armstrong, S. L., Stahl, N. A., \& Kantner, M. J. (2015). Investigating academic literacy expectations: A curriculum audit model. Journal of Developmental Education, 38(2), 2-23.

Au, K., \& Raphael, T. (2000). Equity and literacy in the next millennium. Reading Research Quarterly, 35(1), 170-188. https://doi.org/10.1598/RRQ.35.1.12

Barton, M. L. (1997). Addressing the literacy crisis: Teaching reading in the content areas. NASSP Bulletin, 81(587), 22-30. https://doi.org/10.1177/019263659708158705

Cox, S. R., Friesner, D. L., \& Khayum, M. (2003). Do reading skills courses help underprepared readers achieve academic success in college? Journal of College Reading and Learning, 33(2), 170-196. https://doi.org/10.1080/10790195.2003.10850147

Delighted, LLC. (2021), What is a good survey response rate for online customer surveys? Retrieved from https://delighted.com/blog/average-survey-response-rate

Donham, J. (2014). College ready - What can we learn from first-year college assignments? An examination of assignments in Iowa colleges and universities. School Library Research, 17, 1-21.

Dupuis, M. M., Askov, E. N., \& Lee, J. W. (1979). Changing attitudes toward content area reading: The content area reading project. Journal of Educational Research, 73(2), 66-74. https://doi.org/10.1080/00220671.1979.10885210

Ellis, S., \& Rowe, A. (2020). Literacy, social justice and inclusion: a large-scale design experiment to narrow the attainment gap linked to poverty. Support for Learning, 35(4), 418-439. https://doi.org/10.1111/1467-9604.12324

Elton, L. (2010). Academic writing and tacit knowledge. Teaching in Higher Education, 15(2), 151-160. https://doi.org/10.1080/13562511003619979

Falk-Ross, F. C. (2001). Toward the new literacy: Changes in college students' reading comprehension strategies following reading/writing projects. Journal of Adolescent \& Adult Literacy, 45(4), 278-288.

Feister, L. (2010). Early warning! Why reading by the end of third grade matters. Annie E. Casey Foundation.

Frankel, K., Becker, B., Rowe, M., \& Pearson, P. D. (2016). From “what is reading?" to what is literacy? Journal of Education, 3(196), 7-17. https://doi.org/10.1177/002205741619600303

French, R. P. (2016). The fuzziness of mindsets: Divergent conceptualizations and characterizations of mindset theory and praxis. International Journal of Organizational Analysis, 24(4), 673-691. https://doi.org/10.1108/IJOA-09-2014-0797

Gilbert, J., \& Fister, B. (2011). Reading, risk, and reality: College students and reading for pleasure. College \& Research Libraries, 72(5), 474-495. https://doi.org/10.5860/crl-148

Glotfelter, A., Updike, A., \& Wardle, E. (2020). Something invisible Has been made visible for me: An expertise-based WAC seminar model grounded in theory and (cross) disciplinary dialogue. In L. E. Bartlett, S. L. Tarabochia, A. R. Olinger, \& M. J. Marshall (Eds.), Diverse approaches to teaching, learning, and writing across the curriculum: IWAC at, 25 (pp 167-192). University Press of Colorado. https://doi.org/10.37514/PER-B.2020.0360.2.10

Gorski, P., \& Swalwell, K. (2015). Equity literacy for all. Educational Leadership, 61, 34-40.

Greene, J., \& Forster, G. (2003). Public high school graduation and college readiness rates in the United States. Center for Civic Innovation at the Manhattan Institute.

Gregory, K. H. (2018). A multi case study of community college discipline faculty's participation in a disciplinary literacy professional learning community. Doctor of Philosophy $(\mathrm{PhD})$, dissertation, Teaching and Learning, Old Dominion University.

Gregory, K. H., \& Bean, T. W. (2020). Trades-based literacy: Community college faculty's exploration of disciplinary literacy. Journal of College Reading and Learning, 51(1), 34-57.

https://doi.org/10.1080/10790195.2020.1791279 
Gregory, K. H., \& Colclough, M. (2018). Community college discipline faculty perceptions of role as literacy educators. Inquiry: The Journal of the Virginia Community Colleges, 21(1). https://commons.vccs.edu/inquiry/vol21/iss $1 / 4$

Gruenbaum, E. A. (2012). Common literacy struggles with college students: Using the reciprocal teaching technique. Journal of College Reading and Learning, 42(2), 109-116. https://doi.org/10.1080/10790195.2012.10850357

Hinton, K., \& Suh, Y. (2019). Foregrounding collaboration in disciplinary literacy: Implications from JAAL, 2008-2017. Journal of Adolescent and Adult Literacy, 3(63), 279-287. https://doi.org/10.1002/jaal.986

Hoeft, M. E. (2012). Why university students don't read: What professors can do to increase compliance. International Journal for the Scholarship of Teaching and Learning, 6(2), n2. https://doi.org/10.20429/ijsotl.2012.060212

Holschuh, J. P. (2019). College reading and studying: The complexity of academic literacy task demands. Journal of Adolescent \& Adult Literacy, 62(6), 599-604. https://doi.org/10.1002/jaal.876

Howard, C. M., Moret, L., Faulconer, J., Cannon, T., \& Tomlin, A. (2018). Preparing for college success: Exploring undergraduate students' perceptions of the benefits of a college reading and study skills course through action research. Networks: An Online Journal for Teacher Research, 20(1). Retrieved from https://doi.org/10.4148/2470-6353.1258

International Literacy Association. (2020). Literacy glossary. Retrieved from https://literacyworldwide.org/get-resources/literacy-glossary

James, I., \& Okpala, C. O. (2010). The use of metacognitive scaffolding to improve college students' academic success. Journal of College Teaching \& Learning (TLC), 7(11), 47-50. https://doi.org/10.19030/tlc.v7i11.251

Jansen, E. P., \& van der Meer, J. (2012). Ready for university? A cross-national study of students' perceived preparedness for university. The Australian Educational Researcher, 39(1), 1-16. https://doi.org/10.1007/s13384-011-0044-6

Johns, A. (1997). Text, role and context: developing academic literacies. Cambridge University Press. https://doi.org/10.1017/CBO9781139524650

Keefe, E., \& Copeland, S. (2011). What is literacy? The power of a definition. Research and Practice for Persons with Severe Disabilities, 36(3-4), 92-99. https://doi.org/10.2511/027494811800824507

Kirst, M. (2014). College is not for everybody: Stop pretending it is. The college puzzle. https://collegepuzzle.stanford.edu/college-is-not-for-everybody-stop-pretending-it-is/

Lampi, J. P., Holschuh, J. P., Reynolds, T., \& Rush, L. S. (2019). Using disciplinary approaches for reading literary texts in developmental literacy courses. Journal of College Reading and Learning, 49(3), 244-251. https://doi.org/10.1080/10790195.2019.1631231

Manzo, A., \& Manzo, U. (1990). Content area reading: A heuristic approach. Merrill.

Moon, A., Gere, A. R., \& Shultz, G. V. (2018). Writing in the STEM classroom: Faculty conceptions of writing and its role in the undergraduate classroom. Science Education, 102, 1007-1028. https://doi.org/10.1002/sce.21454

Nathan, M. J., Koedinger, K. R., \& Alibali, M. W. (2001). Expert blind spot: When content knowledge eclipses pedagogical content knowledge. Proceedings of the third international conference on cognitive science.

Norris, S. P., \& Phillips, L. M. (2003). How literacy in its fundamental sense is central to scientific literacy. Science Education, 87, 224-240. https://doi.org/10.1002/sce.10066

Organization for Economic Cooperation and Development. (2006). Assessing scientific, reading and mathematical literacy: A framework for PISA 2006. Paris: OECD Publications.

Paulson, E. J., \& Armstrong, S. L. (2010). Postsecondary literacy: Coherence in theory, terminology, and teacher preparation. Journal of Developmental Education, 33(3), 4.

Pawan, F., \& Honeyford, M. (2009). Academic literacy. In R. F. Flippo \& D. C. Caverly (Eds.), Handbook of college reading and study strategy research, $2 n d$ ed., (pp. 26-46). Routledge.

Penrose, A. M. (2002). Academic literacy perceptions and performance: Comparing first-generation and continuing-generation college students. Research in the Teaching of English, 36(4), 437-461. 
Perin, D. (2013). Literacy skills among academically underprepared students, Community College Review, 54(2), 118-136. https://doi.org/10.1177/0091552113484057

Perin, D., Holschuh, J. P. (2019). Teaching academically underprepared postsecondary students. Review of Research in Education, 43(1), 363-393. https://doi.org/10.3102/0091732X18821114

Pugh, S. L., Pawan, F., \& Antommarchi, C. (2000). Academic literacy and the new college learner. In R. F. Flippo \& D. C. Caverly (Eds.), Handbook of college reading and study research (pp. 25-42). Erlbaum.

Reed, E., \& Justice, M. (2014). College and high school educators' perceptions of current college readiness levels. International Journal of Humanities and Social Science, 4(14), 37-44.

Rosenblatt, L. M. (1994). The reader, the text, the poem: The transactional theory of the literary work. Southern Illinois University Press.

Ruddell, R. B., \& Unrau, N. J. (2004). Processes of reading and literacy. In R. B. Ruddell \& N. J. Unrau (Eds.), Theoretical models and processes of reading 5th ed., (pp. 94-115). International Reading Association. https://doi.org/10.1598/0872075028

Selman, M. (2017). Perspectives of secondary and postsecondary faculty on student college readiness. Sam Houston State University. (Doctoral dissertation).

Shanahan, T., \& Shanahan, C. (2012). What is disciplinary literacy and why does it matter? Topics in Language Disorders,32(1), 7-18. https://doi.org/10.1097/TLD.0b013e318244557a

Smagorinsky, P. (2001). If meaning is constructed, what's it made from? Toward a cultural theory of reading. Review of Educational Research, 71(1), 133-169. https://doi.org/10.3102/00346543071001133

Stobierski, T. (2020). Average salary by education level: the value of a college degree. Northwestern University. Retrieved from https://www.northeastern.edu/bachelors-completion/news/average-salary-by-education-level/

Stroumbakis, K., Moh, N., \& Kokkinos, D. (2010). Community College STEM faculty views on the value of writing assignments. WAC Journal, 27, 142-153. https://doi.org/10.37514/WAC-J.2016.27.1.08

Tatum, A. W. (2008). Towards a more anatomically complete model of literacy instruction: A focus on African-American males. Harvard Education Review, 78(1), 1-55. https://doi.org/10.17763/haer.78.1.6852t5065w30h449

Theriault, J. C., Hoff, M. A., \& Castillo, A. M. (2020). Supporting diverse learners: Insights to keep in MIND from the field of developmental education Journal of College Reading and Learning, 50(4), 267-275. https://doi.org/10.1080/10790195.2020.1817813

Trostel, P. (2015). It's not just the money: The benefits of college education to individuals and to society. Margaret Chase Smith Policy Center and School for Economics (University of Maine) and Lumina Issue Papers, 4. Retrieved from https://www.luminafoun dation.org/resources/its-not-just-the-money

Wallaert, K. (2018). College readiness as perceived by first-year community college students taking remedial courses. Doctoral dissertation, Walden University.

Weideman, A. (2014). Academic literacy: Why is it important? In A. Weideman \& T. van Dyk (Eds.), Academic literacy: test your competence (pp. ii-ix). Geronimo Distribution.

Wingate, U. (2016). Academic literacy across the curriculum: towards a collaborative instructional approach. Language Teaching, 51(3), 1-6. https://doi.org/10.1017/S0261444816000264

Yancey, K. B. (2009). The literacy demands of entering the university. In L. Christenbury, R. Bomer \& P. Smagorinsky (Eds.), Handbook of adolescent literacy research (pp. 256-270). New York, NY: Guilford.

Yosso, T., Smith, W., Ceja, M., \& Solórzano, D. (2009). Critical race theory, racial microaggressions, and campus racial climate for Latina/o undergraduates. Harvard Educational Review, 79(4), 659-691. https://doi.org/10.17763/haer.79.4.m6867014157m7071

\section{Copyrights}

Copyright for this article is retained by the author(s), with first publication rights granted to the journal.

This is an open-access article distributed under the terms and conditions of the Creative Commons Attribution license (http://creativecommons.org/licenses/by/4.0/). 